\title{
EGL-1 BH3 mutants reveal the importance of protein levels and target affinity for cell-killing potency
}

\author{
EF Lee ${ }^{1}$, L Chen ${ }^{1}$, H Yang ${ }^{1}$, PM Colman', DCS Huang ${ }^{1}$ and WD Fairlie*,1
}

Studies of the cell death pathway in the nematode Caenorhabditis elegans provided the first evidence of the evolutionary conservation of apoptosis signalling. Here we show that the worm Bcl-2 homology domain-3 (BH3)-only protein EGL-1 binds mammalian pro-survival proteins very poorly, but can be converted into a high-affinity ligand for $B c l-2$ and $B c l-x_{L}$ by subtle mutation of the cysteine residue at position 62 within the BH3 domain. A 100-fold increase in affinity was observed following a single atom change (cysteine to serine substitution), and a further 10 -fold increase by replacement with glycine. The low affinity of wild-type EGL-1 for mammalian pro-survival proteins and its poor expression correlates with its weak killing activity in mammalian cells whereas the high-affinity C62G mutant is a very potent killer of cells lacking Mcl-1. Cell killing by the C62S mutant with intermediate affinity only occurs when this EGL-1 BH3 domain is placed in a more stable context, namely that of $\mathrm{Bim}_{\mathrm{S}}$, which allows higher expression, though the kinetics of cell death now vary depending on whether Mcl-1 is neutralized by Noxa or genetically deleted. These results demonstrate how levels of BH3-only proteins, target affinity and the spectrum of neutralization of pro-survival proteins all contribute to killing activity.

Cell Death and Differentiation (2008) 15, 1609-1618; doi:10.1038/cdd.2008.86; published online 20 June 2008

Landmark studies in Caenorhabditis elegans revealed that four genes, CED-9, CED-4, CED-3 and EGL-1, are essential for the programmed cell death (apoptosis) of 131 out of 1090 somatic cells during hermaphrodite nematode development. ${ }^{1}$ Of these, EGL-1, CED-3 and CED-4 encode pro-apoptotic proteins whereas CED-9 encodes a pro-survival protein. CED-9 is the nematode homologue of mammalian B-cell lymphoma-2 (Bcl-2) pro-survival proteins (including Bcl-2 itself as well as $\mathrm{Bcl}-\mathrm{x}_{\mathrm{L}}$, Bcl-w, Mcl-1 and A1), ${ }^{2}$ while CED-4 is similar to the mammalian adapter protein APAF- $1^{3}$ acting as a positive regulator of caspases, in particular, CED-3. ${ }^{4}$ EGL-1 is the nematode Bcl-2 homology domain-3 $(\mathrm{BH} 3)$-only protein equivalent to mammalian BH3-only proteins such as Bim, Bad and Noxa. ${ }^{5-7}$

In nematode cells, CED-9 functions by sequestering CED-4 at the mitochondrial membrane..$^{8-10}$ Following a developmental cue, EGL-1 is transcriptionally upregulated and the protein binds CED-9, ${ }^{5-7}$ releasing CED-4, allowing its oligomerization. ${ }^{11}$ These CED-4 oligomers then translocate to the perinuclear region of the cell ${ }^{12}$ where they facilitate CED-3 activation by bringing these caspases into close proximity. ${ }^{4,9}$ Biochemical and structural studies have revealed that binding of the EGL-1 BH3 domain into a hydrophobic groove on CED-9 causes a conformational change at the CED-4:CED-9 interface that results in CED-4 dissociation. ${ }^{13-15}$ The $\mathrm{BH} 3$ domains of mammalian $\mathrm{BH} 3-$ only proteins bind into similar grooves on mammalian pro-survival molecules, but a conformational change as seen in CED-9 has yet to be observed. ${ }^{16-18}$

The functional equivalence, and hence evolutionary conservation, of CED-9 and mammalian $\mathrm{Bcl}-2$ was demonstrated in studies showing Bcl-2 could inhibit apoptosis in the nematode. ${ }^{2,19}$ More recently, studies employing yeast-based functional and other biochemical assays determined that in the nematode studies described above, Bcl-2 is probably functioning by binding to EGL-1 thereby preventing its association with CED-9. ${ }^{20}$ However, although CED-9 appears able to prevent cellular processes such as mitochondrial fission in mammalian cells (suggesting potential interactions with mammalian proteins), ${ }^{21}$ EGL-1 seems ineffective at inducing apoptosis. ${ }^{21}$ We have also shown that mammalian $\mathrm{BH} 3-$ only proteins such as Bim and Bad, unlike EGL-1, cannot dissociate CED-4:CED-9 complexes. ${ }^{22}$ This suggests that either these mammalian $\mathrm{BH} 3-$ only proteins cannot engage CED-9 directly, or alternatively, they bind CED-9 but cannot induce the conformational change necessary for CED-4 release. ${ }^{11}$

These studies indicate that the molecular mechanisms, and evolutionary conservation, of nematode and mammalian apoptosis pathways are still not completely understood. Here we have performed detailed biochemical analyses of mammalian and nematode $\mathrm{BH} 3$ domain:pro-survival protein interactions. We demonstrate that certain mammalian $\mathrm{BH} 3$ domains cannot bind CED-9 with high affinity, and surprisingly, that EGL-1 is a weak ligand for mammalian pro-survival molecules, accounting for its weak/absent apoptotic activity in mammalian cells. Importantly, we also discovered that subtle mutations convert EGL-1BH3 into a tightly binding ligand for select mammalian Bcl-2 proteins. By examining the ability of these mutants to kill mammalian cells we determined that both their affinity and sequence context, which influenced

\footnotetext{
${ }^{1}$ The Walter and Eliza Hall Institute of Medical Research, 1G Royal Parade, Parkville, Victoria 3050, Australia

*Corresponding author: WD Fairlie, Structural Biology Division, The Walter and Eliza Hall Institute of Medical Research, 1G Royal Parade, Parkville, Victoria 3050, Australia. Tel: + 6139345 2689; Fax: + 6139345 2686; E-mail: fairlie@ wehi.edu.au Keywords: apoptosis; Bcl-2; BH3 domain; Caenorhabditis elegans; EGL-1; threshold Abbreviations: Bcl-2, B-cell lymphoma-2; BH3, Bcl-2 homology domain-3; ITC, isothermal titration microcalorimetry; MEF, mouse embryonic fibroblast Received 08.1.08; revised 14.5.08; accepted 22.5.08; Edited by D Vaux; published online 20.6.08
} 
a

\begin{tabular}{|c|c|}
\cline { 2 - 2 } \multicolumn{1}{c|}{} & $\mathrm{IC}_{50}(\mathrm{nM})$ \\
\hline $\mathrm{BCl}-2$ & 7,100 \\
\hline $\mathrm{BCl}-\mathrm{x}_{\mathrm{L}}$ & 30,000 \\
\hline $\mathrm{BCl}-\mathrm{w}$ & $>50,000$ \\
\hline $\mathrm{MCl}-1$ & $>50,000$ \\
\hline $\mathrm{A} 1$ & 7,500 \\
\hline
\end{tabular}

C FLAG-CED-9 b
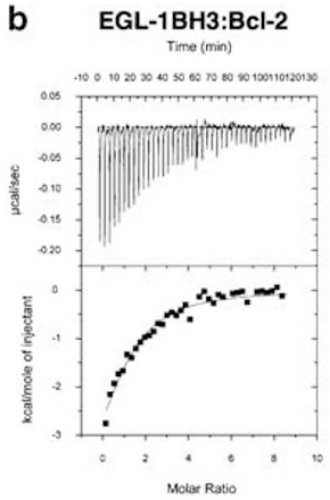

HA-Bim +
EGL-1BH3:Buffer Time (min)

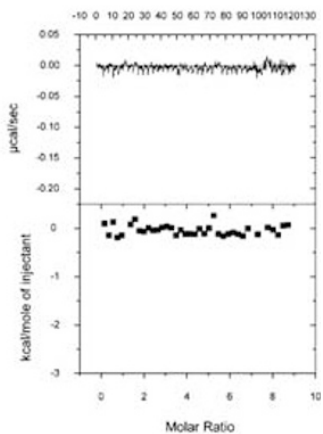

HA-Bim $4 E$ +

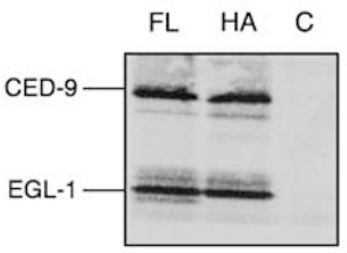

FLAG-Bcl-2

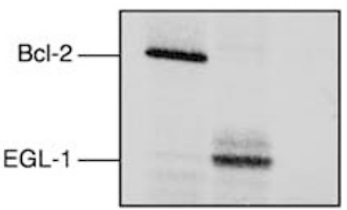

FLAG-Bcl- $x_{L}$

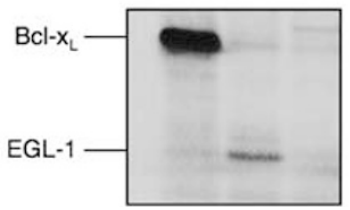

FL HA C
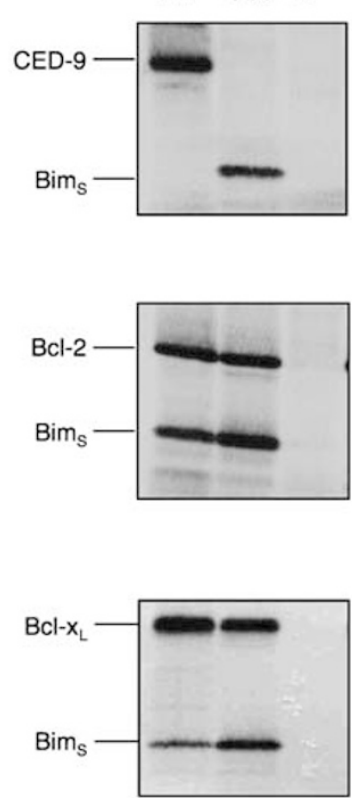

FL HA C
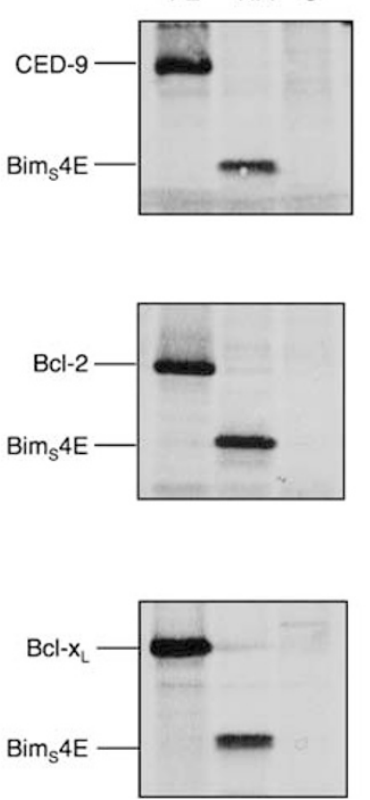

Figure 1 EGL-1 binds only certain mammalian pro-survival Bcl-2 proteins weakly. (a) IC ${ }_{50}$ values determined by solution competition assays using EGL-1BH3 peptide and mammalian pro-survival proteins. EGL-1 can only bind some of the mammalian Bcl-2 proteins very weakly in contrast to the much stronger affinity (low nM) for CED-9. ${ }^{13,14,22}$ (b) The weak interaction between Bcl-2 and EGL-1 was confirmed by isothermal titration microcalorimetry (ITC) where a $K_{\mathrm{D}}$ of $10 \mu \mathrm{M}$ was determined (left). The control titration of the peptide alone into buffer is also shown (right). (c) Confirmation of the weak in vitro binding. Interactions between FLAG (FL)-tagged CED-9, Bcl-- $\mathrm{L}_{\mathrm{L}}$ or Bcl-2 and HA-

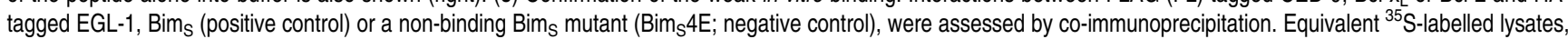
harvested from transiently transfected 293T cells, were co-immunoprecipitated with antibodies to the FLAG (FL), HA or control (C) anti-glu tags

intracellular expression levels/stability, together with how Mcl-1 was inactivated, determined their cell-killing kinetics and potency.

\section{Results}

EGL-1BH3 binds mammalian pro-survival Bcl-2 proteins weakly. Although previous studies suggest that mammalian pro-survival proteins interact with EGL-1, ${ }^{20}$ others demonstrated that EGL-1 is ineffective at killing mammalian cells. $^{6,21}$ To better understand this paradox, we measured the affinity of EGL-1BH3 for mammalian pro-survival proteins. The ability of the worm pro-survival protein CED-9 to bind to BimBH3, a 'promiscuous' mammalian $\mathrm{BH} 3$ domain, was also assessed.
Solution competition experiments using the Biacore optical biosensor demonstrated that an EGL-1BH3 26-mer synthetic peptide bound a subset of mammalian pro-survival proteins, but did so only relatively weakly with the highest affinities measured for Bcl-2 and $\mathrm{A} 1\left(\mathrm{IC}_{50}, 7-8 \mu \mathrm{M}\right.$; Figure 1a). Typical high-affinity interactions between mammalian $\mathrm{BH} 3$ peptides and pro-survival proteins give $I_{50}$ values in similarly performed assays in the low nanomolar range. ${ }^{23}$ The affinity measured for $\mathrm{BCl}-\mathrm{x}_{\mathrm{L}}$ was even weaker $\left(\mathrm{IC}_{50}, 30 \mu \mathrm{M}\right)$, and undetectable for $\mathrm{Mcl}-1$ or $\mathrm{Bcl}-\mathrm{w}$. We confirmed the binding interaction between $\mathrm{Bcl}-2$ and $\mathrm{EGL}-1$ using isothermal titration microcalorimetry (ITC), where a $K_{\mathrm{D}}$ of approximately $10 \mu \mathrm{M}$ was determined (Figure $1 \mathrm{~b}$ ), consistent with the Biacore results.

As the Biacore assay was dependent on pro-survival proteins binding an immobilized BimBH3 peptide, CED-9 
could not be assessed in this assay as no interaction was detected, suggesting that the affinity of CED-9 for BimBH3 is also very weak. This was confirmed by ITC where no interaction was detected (data not shown), consistent with previous results. ${ }^{22}$

To determine that the binding affinity data for the $\mathrm{BH} 3$ peptides accurately reflected the ability of full-length $\mathrm{BH} 3-$ only proteins to interact with pro-survival proteins, we performed co-immunoprecipitation experiments using over-expressed full-length proteins in HEK293T cells (Figure 1c). As expected, a strong interaction was observed between wild-type EGL-1 and CED-9, but not with Bcl-2 or Bcl- $\mathrm{x}_{\mathrm{L}}$, consistent with the low affinity of the EGL-1BH3 peptide measured for these proteins (Figure 1a). Similarly, full-length Bim $\mathrm{S}$ was unable to co-immunoprecipitate with CED-9, but a strong interaction was observed with $\mathrm{Bcl}-2$ and $\mathrm{Bcl}-\mathrm{x}_{\mathrm{L}}$. Finally, as a negative control, we showed that a Bim $\mathrm{S}_{\mathrm{S}}$ mutant $\left(\mathrm{Bim}_{\mathrm{S}} 4 \mathrm{E}\right)$ with $\mathrm{BH} 3$ domain mutations rendering it incapable of binding any (mammalian) pro-survival molecules ${ }^{23}$ was unable to coimmunoprecipitate any FLAG-tagged proteins examined.

Together these results demonstrate that EGL-1 is a weak ligand for mammalian pro-survival proteins. Furthermore, Bim, which binds all mammalian pro-survival proteins with high affinity, is incapable of interacting with the worm prosurvival molecule, CED-9.

Subtle mutations of EGL-1BH3 convert it to a highaffinity ligand for some mammalian pro-survival proteins. The low affinity of EGL-1 for mammalian prosurvival proteins was unexpected as its $\mathrm{BH} 3$ domain shares most of the key features of mammalian $\mathrm{BH} 3$ domains (Figure 2a). In particular, the conserved hydrophobic residues ( $\mathrm{h} 1-\mathrm{h} 4$ in Figure $2 \mathrm{a}$ ) that project into the hydrophobic groove on pro-survival molecules ${ }^{16-18,23}$ are similar to corresponding residues found on tightly binding mammalian $\mathrm{BH} 3$ domains. Similarly, the conserved aspartate in all mammalian $\mathrm{BH} 3$ domains is present in EGL-1BH3. One difference we noted in positions that are relatively highly conserved was in the residue immediately before the conserved aspartate (Figure 2a). In most mammalian $\mathrm{BH} 3$ domains this is either glycine or alanine, and in $\mathrm{BadBH} 3$, a serine. However, in EGL-1BH3 the corresponding residue is cysteine, not seen in any mammalian $\mathrm{BH} 3$ domains. We therefore examined the effect of replacing this residue in EGL$1 \mathrm{BH} 3$ with serine or glycine.

Surprisingly, substitution of the cysteine for serine, representing a single atom change (oxygen for sulphur on the side chain) resulted in significant affinity gain for $\mathrm{Bcl}-2$ and $\mathrm{BCl}-\mathrm{x}_{\mathrm{L}}$, and to a slightly lesser extent A1 (Figure 2b). Furthermore, much greater increases in affinity were observed for all pro-survival proteins following substitution of the cysteine with glycine (Figure $2 b$ ).

To determine the effect of the corresponding substitutions in full-length EGL-1 we performed co-immunoprecipitation experiments (Figure 2c). As anticipated, both EGL-1 mutants were capable of strongly co-immunoprecipitating with $\mathrm{Bcl}-\mathrm{x}_{\mathrm{L}}$ and $\mathrm{Bcl}-2$, and no negative effect was seen for the interaction with CED-9. This high affinity for CED-9 was confirmed by ITC where the EGL-1BH3-C62G peptide bound with a $K_{\mathrm{D}}$ of $14 \mathrm{nM}$ (Figure 2d), similar to wild-type EGL-1BH3. ${ }^{13,22}$
Finally, as CED-4:CED-9 complex dissociation is dependent upon a conformational change in CED-9 following EGL-1 binding, ${ }^{13}$ we also determined the effect of substitution of the cysteine residue in EGL-1BH3 peptide on its ability to dissociate recombinant CED-4:CED-9 complex (Figure 2e). Both mutant peptides were able to dissociate the complex as with wild-type EGL-1BH3, but as previously, no dissociation was observed with the $\mathrm{BimBH} 3$ peptide. ${ }^{22}$

These results demonstrate the exquisite sensitivity of prosurvival protein: $\mathrm{BH} 3$ domain interactions and suggest $\mathrm{BH} 3$ domain-binding profiles can be readily manipulated.

EGL-1 is poorly expressed and unstable in mammalian cells. Previous studies indicated that EGL-1 is unstable in mammalian cells, ${ }^{6}$ hence experiments examining its killing activity may be affected by low intracellular concentrations. To explore this possibility we examined the relative levels of HA-tagged EGL-1 and mutants compared to HA-tagged $\mathrm{Bim}_{\mathrm{S}}$ expressed in $\mathrm{bax}^{-/} / \mathrm{bak}^{-/-}$mouse embryonic fibroblasts (MEFs) from retroviruses where expression was linked to green fluorescent protein (GFP) by an internal ribosome entry site. In pools of infected cells (where $>85 \%$ of cells expressed GFP; Figure 3a), Bim was basally expressed at markedly higher levels than EGL-1 or C62S and C62G mutants (Figure $3 b$ ). As this low-level expression in MEFs might influence biological activity, we created Bim $\mathrm{S}$ chimeric constructs where the $\mathrm{Bim}_{\mathrm{S}} \mathrm{BH} 3$ domain was replaced with EGL-1BH3 or EGL-1BH3 mutants. Such chimeras possess the pro-survival protein-binding and cell-killing characteristics of the newly integrated $\mathrm{BH} 3$ sequence. ${ }^{23,24}$ As a consequence we now see much higher basal expression of these chimeras compared to the EGL-1 constructs, though less than parental wild-type Bim $_{S}$ (Figure $3 b$ ). In stability studies where protein synthesis was inhibited with cycloheximide, the C62G mutant of either EGL-1 or $\mathrm{Bim}_{\mathrm{S}} \mathrm{EGL}-1 \mathrm{BH} 3$ persists longer than the wild-type counterpart (Figure $3 \mathrm{c}$ ), perhaps due to their ability to better associate with pro-survival proteins (Figures 1c and 2c), hence shielding them from proteolytic attack. For example, wild-type EGL-1 has a half-life of less than $15 \mathrm{~min}$ whereas EGL-1-C62G persists for 2-4h (Figure 3c).

Wild-type EGL-1 is a poor killer of mammalian cells. We and others have established that diverse pro-survival proteins must be neutralized by BH3-only proteins for apoptosis to proceed, though the exact mechanism of Bak/Bax activation remains controversial. ${ }^{24-28}$ It has been proposed that for Bak-mediated killing, BH3-only proteins must engage both $\mathrm{Mcl}-1$ and $\mathrm{Bcl}-\mathrm{x}_{\mathrm{L}}{ }^{24}$ whereas for $\mathrm{Bax}$, a larger range of pro-survival proteins must be neutralized. ${ }^{25}$ As EGL-1BH3 binds all mammalian pro-survival proteins very weakly, it is not surprising that previous studies have shown EGL-1 to only weakly kill mammalian cells. ${ }^{21}$ We confirmed this in short- $(24 \mathrm{~h})$ and long-term (6 days - clonogenic) survival assays using wild-type MEFs infected with retroviruses expressing full-length EGL-1 (Figure $4 \mathrm{a}$ and $\mathrm{b}$ ).

$m c l-1^{-1-}$ or $b c l-x^{-1-}$ MEFs are sensitive to BH3-only proteins that engage the complementary pro-survival protein. ${ }^{29}$ Hence, although Bad or Noxa are ineffective killers of 
a

Egl-1 (54-65)
Bim $_{\mathrm{s}}(58-69)$
Puma (137-148)
Bmf (133-144)
Bad (110-121)
Bik (57-68)
Hrk (33-44)
Bid (86-97)
Noxa (25-36)

\begin{tabular}{|c|c|c|c|c|c|c|c|c|c|c|c|}
\hline & & & & h2 & & & & & & & \\
\hline & G & $\mathrm{s}$ & $\mathrm{K}$ & L & A & A & M & $c$ & $D$ & $D$ & \\
\hline & A & $Q$ & $E$ & L & R & R & 1 & G & D & $E$ & \\
\hline & G & A & $Q$ & L & R & R & M & A & D & D & \\
\hline & A & $R$ & K & L & $Q$ & $c$ & 1 & A & D & $Q$ & \\
\hline & $G$ & $R$ & $\mathrm{E}$ & L & R & R & M & s & D & $\mathrm{E}$ & \\
\hline & A & L & R & L & A & $c$ & 1 & G & D & $E$ & M \\
\hline & A & A & R & L & $\kappa$ & A & 1 & G & D & E & \\
\hline & A & $R$ & $\mathrm{H}$ & L & A & Q & $v$ & G & D & s & \\
\hline & A & $T$ & Q & L & R & R & $F$ & G & D & K & \\
\hline
\end{tabular}

h4

\begin{tabular}{|c|c|c|}
\hline & \multicolumn{2}{|c|}{$I C_{50}(\mathrm{nM})$} \\
\hline & C62S & C62G \\
\hline $\mathrm{BCl}-2$ & 75 & 9 \\
\hline Bcl- $x_{L}$ & 250 & 14 \\
\hline Bcl-w & 12,000 & 260 \\
\hline $\mathrm{Mcl}-1$ & $>20,000$ & 250 \\
\hline A1 & 470 & 10 \\
\hline
\end{tabular}

C

HA-Egl-1-C62S

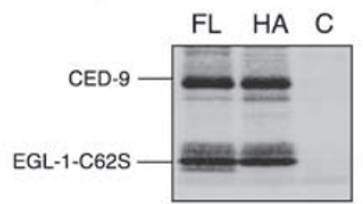

HA-Egl-1-C62G

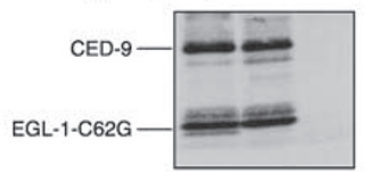

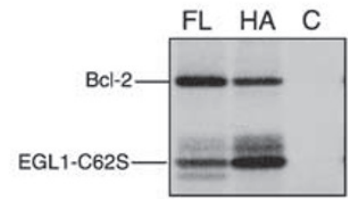

FLAG-Bcl-2 +
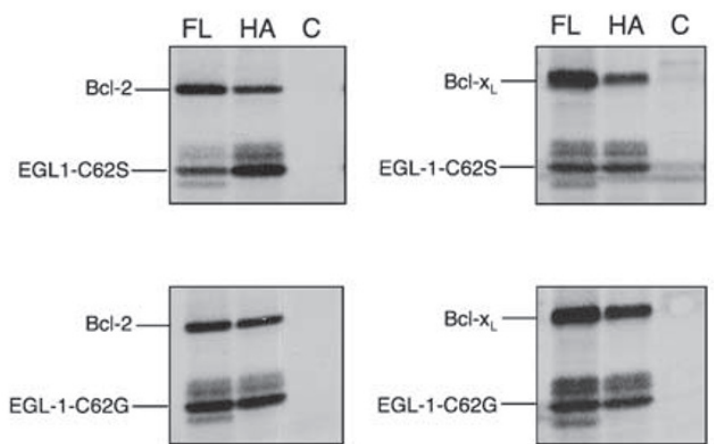

FLAG-Bcl- $\mathbf{x}_{\mathrm{L}}+$

d EGL-1BH3-C62G:CED-9
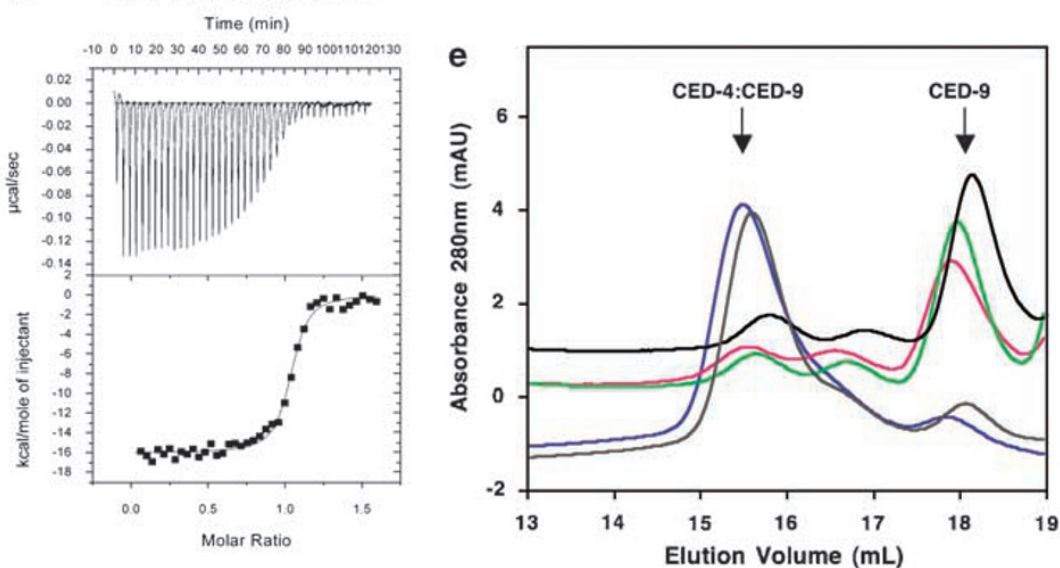

Figure 2 EGL-1 can be converted into a high-affinity ligand for mammalian pro-survival proteins. (a) Sequence comparison of the BH3 domains of EGL-1 and a subset of mammalian BH3 domains. EGL-1 has the key features of mammalian BH3 sequences including the conserved hydrophobic residues (h1-h4) (shaded black) and the conserved aspartate (shaded blue). Although, the residue immediately preceding the aspartate is usually a small amino acid such as glycine or alanine, it is uniquely a cysteine in EGL-1. (b) IC $5_{50}$ values for the binding of EGL-1BH3 mutants to mammalian pro-survival proteins as determined in solution competition assays. Mutation of the cysteine residue at position 62 of EGL-1 to serine or glycine results in significant increases in binding affinity, particularly to Bcl-2 and Bcl-xL. (c) Unlike wild-type EGL-1, full-length EGL1 bearing these mutations can detectably bind to $\mathrm{Bcl}-2$ and $\mathrm{Bcl}-\mathrm{x}_{\mathrm{L}}$ in co-immunoprecipitation experiments performed as in Figure $1 \mathrm{c}$. (d) The C62G mutation does not affect binding to CED-9. Isothermal titration microcalorimetry (ITC) analysis of EGL-1BH3-C62G mutant peptide binding to CED-9. The affinity (14 nM) is equivalent to the wild-type EGL-1BH3 peptide. ${ }^{13,14,22}$ (e) Wild-type and mutant EGL-1BH3 mutant peptides, but not Bim BH3, can dissociate CED-4:CED-9 complexes as effectively as wild-type EGL1BH3. The disappearance of the earlier eluting peak (CED-4:CED-9) and concomitant appearance of a later eluting one (CED-9) is indicative of the CED-4:CED-9 complex dissociation. ${ }^{22}$ Dissociated free CED-4 is not observed in the profile as it precipitates upon dissociation from CED-9 and is removed by centrifugation prior to chromatography, as previously described. ${ }^{22}$ Grey, no peptide treatment; blue, Bim BH3; red, wild-type EGL-1BH3; green, EGL-1BH3-C62S; black, EGL-1BH3-C62G

wild-type MEFs due to their limited binding profiles (Bad targets Bcl- $\mathrm{x}_{\mathrm{L}}, \mathrm{Bcl}-2$ and Bcl-w; Noxa targets Mcl-1), they are able to kill $m c l-1^{-1-}$ and $b c l-x^{-1-}$ MEFs respectively (Figure $4 c$ and d). However, EGL-1 was unable to kill either cell line in short- or long-term assays (Figure 4c and d). As killing activity may have been influenced by poor expression
(Figure 3b), we similarly examined the Bim $_{S} E G L-1$ $\mathrm{BH} 3$ chimera. No killing was observed in any cell line despite relatively higher expression levels (Figure $4 c$ and $d$ ).

We next determined whether our EGL-1 mutants (C62S and $\mathrm{C} 62 \mathrm{G}$ ), which bind mammalian pro-survival proteins with higher affinity than the wild-type sequence (Figure $2 b$ ), would 

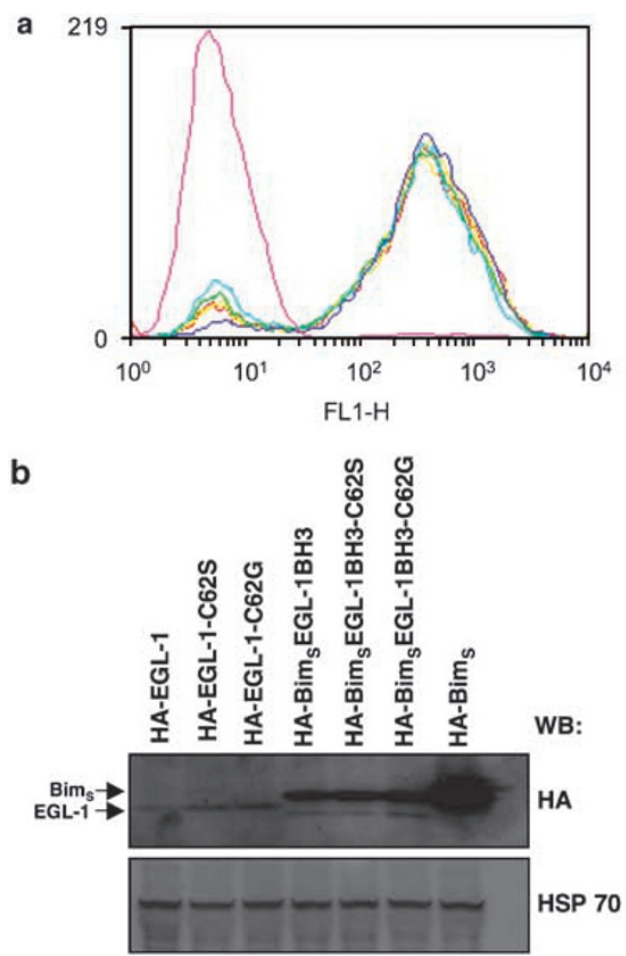

C

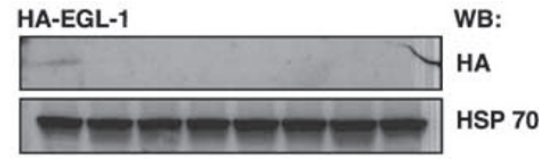

HA-EGL-1-C62G

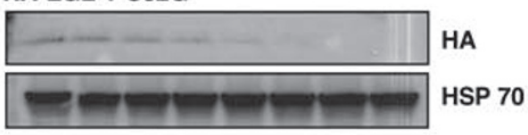

HA-Bim ${ }_{S}$ EGL-1BH3

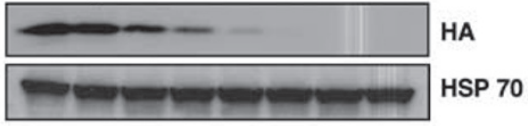

HA-Bim ${ }_{S}$ EGL-1BH3-C62G

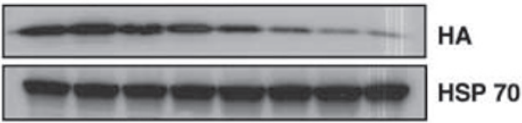

HA-Bim

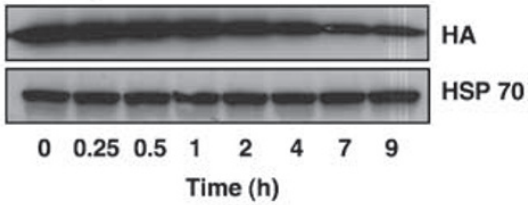

Figure 3 Expression and stability of EGL-1 or its mutants in mammalian cells. (a) FACS plot overlay showing green fluorescent protein (GFP) expression (FL1-H) of

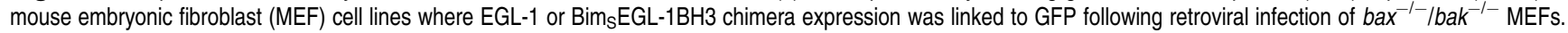

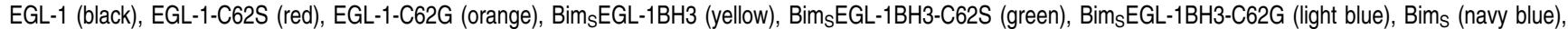
untransfected (pink). (b) Western blot showing basal-level expression of HA-tagged EGL-1 and Bim $\mathrm{S}_{\mathrm{S}} \mathrm{GL}-1$ chimeras from equivalent cell lysates derived from lines shown in (a). Blots were re-probed with anti-HSP 70 as a loading control. Note the strikingly low levels of wild-type or mutant EGL-1. (c) Cells from (a) were either left untreated or exposed to $50 \mu \mathrm{g} / \mathrm{ml}$ cycloheximide for the indicated times after which they were analysed by western blotting using the anti-HA antibody. The C62G mutants of EGL-1BH3 (compare second with fourth panel) appeared more stable especially in the context of Bims, potentially because they can associate with endogenous pro-survival proteins such as Bcl-2. Blots were re-probed for anti-HSP 70 as a loading control

be able to kill the same cell lines. As these mutants displayed enhanced affinity for $\mathrm{Bcl}-2$ and $\mathrm{Bcl}-\mathrm{x}_{\mathrm{L}}$ in particular, we predicted they would behave similarly to Bad, only killing $m c l-1^{-1-}$ cells, but not wild-type or $b c l-x^{-1-}$ MEFs. Indeed, neither mutant was able to kill the wild-type or $b c /-x^{-/}$MEFs in the short- or long-term assays (Figure 4a-d). Importantly, unlike the wild-type EGL-1BH3 domain, both EGL-1BH3 mutants displayed potent killing of $\mathrm{mcl}^{-1^{-1}}$ MEFs in the context of the Bims backbone in short- and long-term assays. Moreover, although the C62G mutant was also an effective killer in the parental EGL-1 context, the C62S mutant did not kill in either assay (Figure $4 a-d)$. Hence our data demonstrate that a combination of expression levels and binding affinity dictates killing activity.

EGL-1BH3 mutants can complement Noxa for cell killing. Co-expression of BH3-only proteins such as Bad and Noxa possessing restricted binding profiles kills cells such as MEFs, though expression of either alone does not. ${ }^{23}$ Both EGL-1-C62S and C62G possess restricted binding profiles similar to $\mathrm{Bad}$, and as such were unable to kill wild-type MEFs regardless of their context (i.e. in the EGL-1 or Bims backbone). We next examined their ability to complement Noxa for cell killing. Again wild-type EGL-1 and $\operatorname{Bim}_{S} E G L-1$ were ineffective, unable to kill Noxaexpressing wild-type MEFs in short- or long-term assays
(Figure 5a and b), while Bim ${ }_{S} E G L-1 B H 3-C 62 S$ was only effective in the long-term assay (Figure $5 a$ and b). EGL-1C62G also only killed Noxa-expressing MEFs in long-term assays whereas the $\operatorname{Bim}_{S} E G L-1 B H 3-C 62 G$ variant was a potent killer in short- and long-term assays. No constructs were able to kill Bad-expressing MEFs, though these were readily killed by Noxa in short-term assays, supporting the specificity of the EGL-1 constructs.

As the release of cytochrome $c$ from mitochondria is a hallmark of apoptosis, we examined the ability of EGL-1BH3 synthetic peptides to induce cytochrome $c$ release from permeabilized cells expressing Noxa or Bad. Consistent with the killing results, wild-type EGL-1BH3 was unable to release cytochrome $c$ in either cell line, although significant release was observed with EGL-1BH3-C62G in the Noxa-expressing cells, but not those expressing Bad (Figure $5 \mathrm{c}$ ).

EGL-1BH3-binding kinetics. Although Biacore competition assays provide a relative measure of binding affinities, allowing comparison between proteins, they do not provide affinity dissociation constants $\left(K_{\mathrm{D}}\right)$, nor do they provide information about binding kinetics. We established an assay using an S51 Biacore biosensor that allows direct measurement of both these parameters for peptides, though only have robust assays for $\mathrm{Mcl}-1$ and $\mathrm{Bcl}-\mathrm{x}_{\mathrm{L}}$. Importantly, the $K_{\mathrm{D}} \mathrm{S}$ show the same trend as in the 

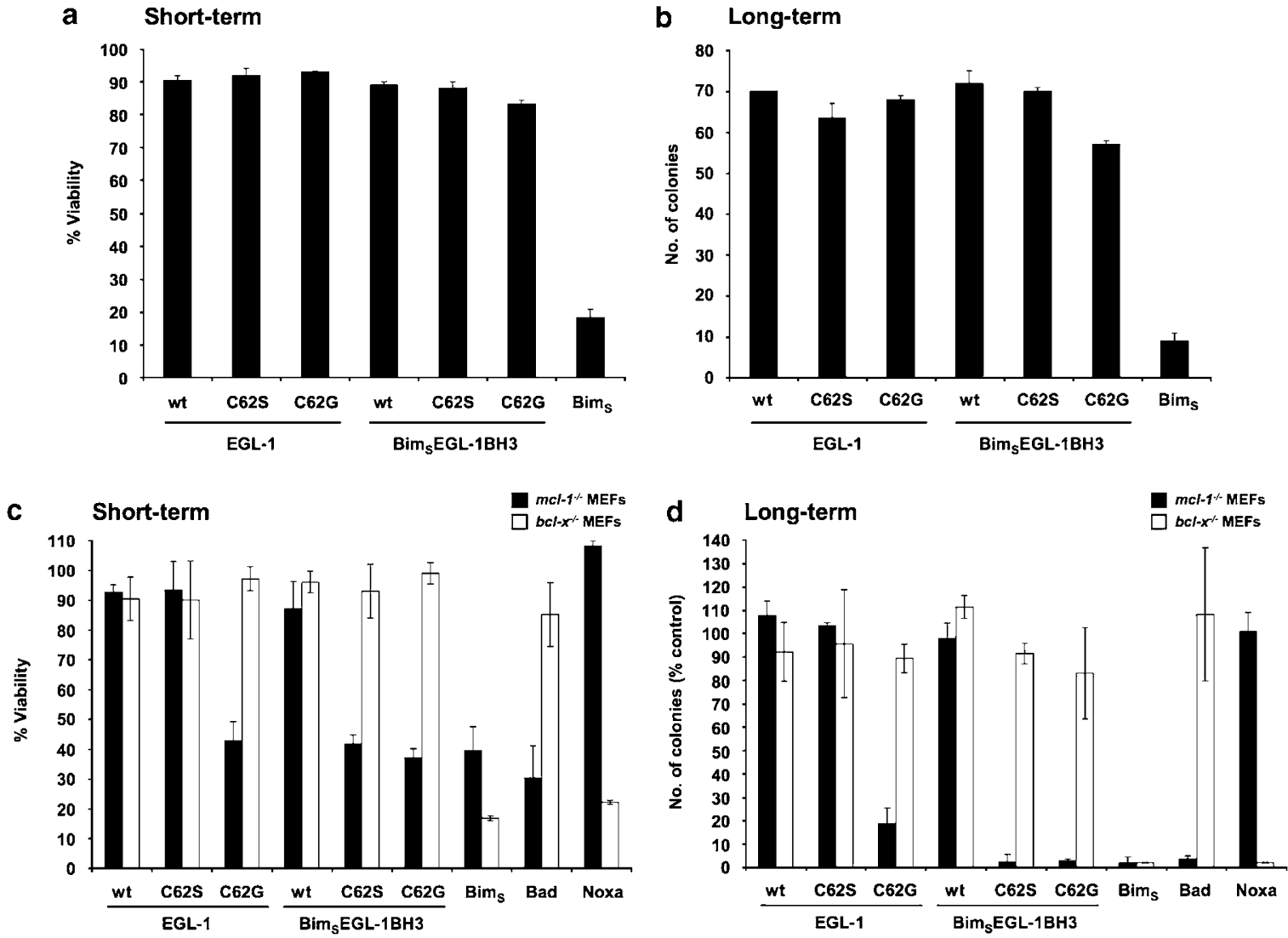

Figure 4 Wild-type EGL-1 is a poor killer of mouse embryonic fibroblasts (MEFs). To evaluate the cytotoxic effect of EGL-1 over-expression, retroviruses expressing either $\mathrm{Bim}_{\mathrm{S}}$, wild-type EGL-1BH3 or EGL-1BH3 mutants, both in the EGL-1 or Bim $\mathrm{S}$ backbones, were used to infect wild-type MEFs (a, b). Cell viability was assessed either (a) $24 \mathrm{~h}$ after infection by propidium iodide exclusion analysed by flow cytometry, or (b) 6 days after infection when colonies were scored. Similar assays were also performed in (c) $\mathrm{mcl}^{-1-1}$ (black bars) or (d) bcl-- ${ }^{-1-}$ (white bars) MEFs. Note that although all EGL-1-based constructs are unable to kill the wild-type cells, significant cell death is observed in $\mathrm{mcl}-1^{-1-}$ cells but not $\mathrm{bcl}-\mathrm{x}^{-1-}$ with the higher affinity ligands. Representative assays are shown where error bars indicate the standard deviation from the mean for duplicate or triplicate data points. All constructs have been tested two or more times in each assay

competition assays, although the data are shifted towards higher affinities (Table 1). The C62G peptide bound almost as tightly to $\mathrm{Bcl}-\mathrm{x}_{\mathrm{L}}$ as $\mathrm{BimBH} 3$. The $\mathrm{C} 62 \mathrm{~S}$ mutant with intermediate affinity has a similar on-rate to $\mathrm{BimBH} 3$ but the complex dissociates nearly 200 -fold more rapidly than the C62G mutant. Essentially no binding was detected for wildtype EGL-1BH3 peptide to Bcl- $x_{\mathrm{L}}$ or Mcl-1. Only the $\mathrm{C62G}$ mutation provided a significant affinity gain for $\mathrm{Mcl}-1$, again consistent with the competition data.

\section{Discussion}

BH3-only protein concentrations and affinities determine apoptotic thresholds. Here we show that EGL-1 binds all mammalian pro-survival proteins weakly and is a poor killer of mammalian cells. However, by manipulating its binding affinity and stability/intracellular concentration, we demonstrated how different combinations of these key biophysical parameters, together with how prosurvival proteins are 'neutralized', determine apoptotic thresholds.

The combination of weak affinity, poor expression and low stability presumably all contribute to wild-type EGL-1 being an inefficient killer of mammalian cells. However, the threshold required to trigger apoptosis cannot be overcome by simply increasing protein levels through the placement of the EGL-1 $\mathrm{BH} 3$ sequence in a more stable context (i.e. Bims), probably because its affinity for pro-survival proteins is still too weak. Nevertheless, incremental increases in killing potency occurred upon manipulation of the above-mentioned parameters (see Table 2 for a summary of killing data).

Probably the single change that had the greatest impact on cell fate was the increase in affinity for $\mathrm{Bcl}-\mathrm{x}_{\mathrm{L}}$ and $\mathrm{Bcl}-2$ from the $\mu \mathrm{M}$ to low-sub-nM range, following the $\mathrm{C} 62 \mathrm{G}$ substitution in EGL-1BH3. Provided Mcl-1 was inactivated (either through Noxa expression or genetic deletion), this mutant was able to kill cells, even when expressed at relatively low levels, as occurs in the parent EGL-1 sequence context.

The EGL-1-C62S mutant that had intermediate affinity for $\mathrm{BCl}-\mathrm{x}_{\mathrm{L}}$ and $\mathrm{Bcl}-2$ was less potent in killing assays than C62G even though it expressed at similar levels. Indeed, EGL-1-C62S was unable to kill MEFs, even when Mcl-1 was also 'neutralized', except when placed in the context of Bim where the protein was present at higher levels. The Bim context may also allow the protein to target the mitochondria more efficiently, hence the improved potency may not be just a consequence of increased levels. 

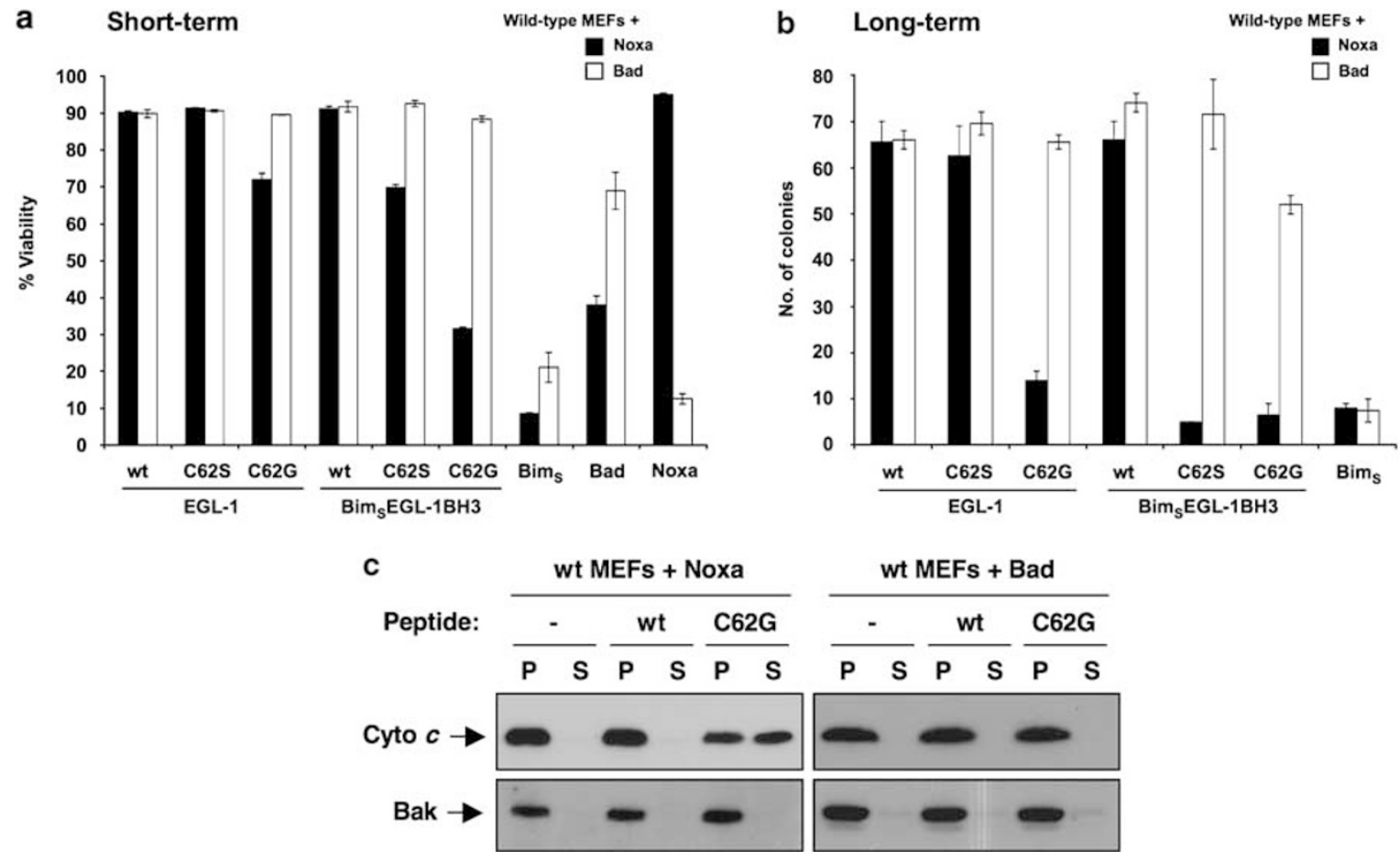

Figure 5 EGL-1 mutants can combine with Noxa to kill mouse embryonic fibroblasts (MEFs). MEFs stably expressing Noxa (black bars) or Bad (white bars) were infected with retroviruses expressing either Bim , wild-type EGL-1BH3 or EGL-1BH3 mutants, both in the EGL-1 or Bims backbones. Cell viability was assessed either (a) $24 \mathrm{~h}$ after infection by propidium iodide exclusion analysed by flow cytometry, or (b) 6 days after infection when colonies were scored. EGL-1 mutants with higher affinities kill Noxaexpressing cells, though the kinetics of cell death depends on the sequence context. Representative assays are shown where the error bars indicate the standard deviation from the mean for duplicate data points. All constructs have been tested two or more times in each assay. (c) EGL-1BH3 peptides were assessed for their ability to release cytochrome $c$ from crude mitochondrial lysates prepared from MEFs expressing either Noxa or Bad. Following incubation with or without (-) indicated peptides (wt, wild-type EGL-1BH3, C62G mutant), lysates were separated into mitochondria-containing pellet ( $P$ ) or soluble $(S)$ fractions. Only the EGL-1-C62G peptide was able to cause release of cytochrome $c$ from the mitochondria from the Noxa-expressing cells. Bak was present only in the pellet fractions of all samples

Table 1 Kinetics of $\mathrm{BH} 3$ domain peptide binding to $\mathrm{Bcl}-\mathrm{x}_{\mathrm{L}}$ and $\mathrm{Mcl}-1$

\begin{tabular}{|c|c|c|c|c|c|c|}
\hline \multirow{2}{*}{$\begin{array}{l}\text { Binding to } \\
\text { Peptide ligand }\end{array}$} & \multicolumn{3}{|c|}{ Bcl- $x_{L}$} & \multicolumn{3}{|c|}{ Mcl-1 } \\
\hline & $K_{\mathrm{D}}(\mathrm{nM})$ & $k_{\mathrm{d}}(1 / \mathrm{s})$ & $k_{\mathrm{a}}(1 / \mathrm{Ms})$ & $K_{\mathrm{D}}(\mathrm{nM})$ & $k_{d}(1 / s)$ & $k_{\mathrm{a}}(1 / \mathrm{Ms})$ \\
\hline $\begin{array}{l}\text { EGL-1BH3 } \\
\text { EGL-1BH3-C62S } \\
\text { EGL-1BH3-C62G } \\
\text { BimBH3 }\end{array}$ & $\begin{array}{c}>5000 \\
29 \\
0.35 \\
0.14\end{array}$ & $\begin{array}{c}N D \\
0.1 \\
6.3 \times 10^{-4} \\
5.3 \times 10^{-4}\end{array}$ & $\begin{array}{c}\text { ND } \\
3.5 \times 10^{6} \\
1.8 \times 10^{6} \\
3.7 \times 10^{6}\end{array}$ & $\begin{array}{c}>5000 \\
>2000 \\
11 \\
0.12\end{array}$ & $\begin{array}{c}N D \\
N D \\
0.03 \\
3.5 \times 10^{-4}\end{array}$ & $\begin{array}{c}\text { ND } \\
\text { ND } \\
2.6 \times 10^{6} \\
2.9 \times 10^{6}\end{array}$ \\
\hline
\end{tabular}

Affinity and kinetic measurements $\left(K_{\mathrm{D}}\right.$, equilibrium dissociation constant; $k_{\mathrm{a}}$, rate constant of association; $k_{\mathrm{d}}$, rate constant of dissociation) were made using a Biacore S51 biosensor where the indicated peptides were injected across a chip in which either $\mathrm{Bcl}-\mathrm{x}_{\mathrm{L}}$ or Mcl-1 was immobilized. ND, not determined as binding was too weak.

We also observed interesting differences in killing kinetics where certain mutants (Bims $\mathrm{EGL}-1 \mathrm{BH} 3-\mathrm{C} 62 \mathrm{~S}$ and EGL-1C62G) were only active in the long-term assay but not in the short-term assay. This difference, though, was only apparent in Noxa-expressing cells. Hence, as these mutants exhibited potent killing in both short- and long-term assays when overexpressed in Mcl-1-deficient cells, it suggests that another event that delays the onset of apoptosis, presumably involving $\mathrm{Mcl}-1$ inactivation, occurs in the Noxa-expressing cells.

One possibility is that there is still some 'functional' $\mathrm{Mcl}-1$ available in the Noxa-expressing cells capable of inhibiting Bak/Bax. We propose that for Mcl-1 to be inactivated, BH3only proteins such as Bim or Bid, which engage $\mathrm{Mcl}-1$ with high affinity ${ }^{23,26}$ (or perhaps bind directly to Bak or $\mathrm{Bax}^{26-28,30}$ ), need to be released from pro-survival protein sequestration. As this displacement involves competition for the same binding site, higher affinity ligands will be more effective as their slower off-rate will mean each binding site is occupied for longer. Alternatively, higher ligand concentrations also favour binding, hence the binding kinetics will translate to the killing kinetics. The slower kinetics of EGL-1-C62G killing in Noxa-expressing cells compared to in the $\mathrm{mcl}-1^{-1-}$ cells likely correlates with its low expression/ concentration, whereas in the case of the Bim $E_{S} E L-1 B H 3-$ C62S mutant this probably relates to its affinity for pro-survival proteins such as Bcl- $x_{\mathrm{L}}$. Furthermore, as EGL-1-C62G (which can engage $\mathrm{Mcl}-1$ ) could not kill Bcl- $\mathrm{x}_{\mathrm{L}}$-deficient or Badexpressing cells, this suggests that the threshold affinity for Mcl-1 was not reached. As the affinity of this ligand was similar to EGL-1-C62S for Bcl- $\mathrm{x}_{\mathrm{L}}$, it appears that the threshold for 
Table 2 Summary of killing activity of EGL-1 and Bim $\mathrm{EGL}-1$ chimeric constructs

\begin{tabular}{|c|c|c|c|}
\hline \multirow{2}{*}{ Ligand } & \multirow{2}{*}{ Cells } & \multicolumn{2}{|c|}{ Assay } \\
\hline & & Short-term & Long-term \\
\hline \multirow{2}{*}{ EGL-1 } & Noxa-expressing & Live & Live \\
\hline & $m c l-1^{-1}$ & Live & Live \\
\hline \multirow{2}{*}{$\mathrm{Bim}_{\mathrm{S}} \mathrm{EGL}-1 \mathrm{BH} 3$} & Noxa-expressing & Live & Live \\
\hline & $m c l-1^{\%}$ & Live & Live \\
\hline \multirow{2}{*}{ EGL-1-C62S } & Noxa-expressing & Live & Live \\
\hline & $m c l-1^{-}$ & Live & Live \\
\hline \multirow{2}{*}{$\mathrm{Bim}_{\mathrm{S}} \mathrm{EGL}-1 \mathrm{BH} 3-\mathrm{C} 62 \mathrm{~S}$} & Noxa-expressing & Live & Die \\
\hline & $m c l-1^{-}$ & Die & Die \\
\hline \multirow{2}{*}{ EGL-1-C62G } & Noxa-expressing & Live & Die \\
\hline & $m c l-1^{\%}$ & Die & Die \\
\hline \multirow{2}{*}{$\mathrm{Bim}_{\mathrm{S}} \mathrm{EGL}-1 \mathrm{BH} 3-\mathrm{C} 62 \mathrm{G}$} & Noxa-expressing & Die & Die \\
\hline & $m c l-1^{-1}$ & Die & Die \\
\hline
\end{tabular}

Mcl-1 neutralization is higher. This difference possibly just reflects a higher intracellular concentration of it compared to $\mathrm{Bcl}-\mathrm{x}_{\mathrm{L}}$. Alternatively, the relative affinities of Bak for $\mathrm{Mcl}-1$ and $\mathrm{Bcl}-\mathrm{x}_{\mathrm{L}}$ need to be considered. Indeed, the higher affinity of the Bak BH3:Mcl-1 interaction compared with Bak $\mathrm{BH}$ : $\mathrm{Bcl}-\mathrm{x}_{\mathrm{L}}$ $\left(\mathrm{IC}_{50} 10\right.$ versus $\left.50 \mathrm{nM}\right)$ is entirely consistent with the higher threshold required for $\mathrm{Mcl}-1$ neutralization. ${ }^{24}$

Hence this model involves elements of both 'indirect' and 'direct' models of apoptotic activation whereby pro-survival proteins act as sinks for BH3-only proteins, though these need not necessarily be 'activators' in the sense proposed previously, rather they exert their pro-apoptotic effect by engaging pro-survival molecules available to inhibit Bax/Bak.

Implications for evolutionary conservation of prosurvival protein function. Our data also highlight how the interconnections between binding affinities and protein levels must be considered when interpreting the classical worm bcl-2 transgene experiments. ${ }^{2,19}$ The low affinity of EGL-1 for most mammalian pro-survival proteins, shown in the present study, is interesting in light of a recent report using a yeast model system. ${ }^{20}$ Their data suggest $\mathrm{Bcl}-2$ does not directly inhibit CED-4, as CED-9 does, but rather acts as a 'sink' to sequester EGL-1, preventing it from engaging CED-9. Our binding data would support this hypothesis provided the levels of $\mathrm{Bcl}-2$ are sufficient to overcome its relatively low affinity $\left(K_{\mathrm{D}} \sim 10 \mu \mathrm{M}\right)$ for $\mathrm{EGL}-1$. Hence, micromolar concentrations of $\mathrm{Bcl}-2$ would be required for a significant proportion of EGL-1 to be sequestered. This is conceivable when $\mathrm{Bcl}-2$ is over-expressed, such as in both the worm and yeast studies. Moreover, as Bcl-2 is predominantly located on mitochondrial membranes, it may have an even higher local concentration. Interestingly, of the mammalian pro-survival proteins, Bcl-2 (together with $\mathrm{A} 1$ ) has the highest affinity for EGL-1 (Figure 1a). Hence, in the light of our binding data, it would be predicted that if $\mathrm{Mcl}-1$ was used instead of $\mathrm{Bcl}-2$ in the classic worm transgene studies, ${ }^{2,19}$ far less, if any pro-survival activity would be observed.

Subtle mutations influence $\mathrm{BH} 3$ domain affinity and specificity. One key finding of this study was that mammalian pro-survival proteins are exquisitely sensitive to small alterations in $\mathrm{BH} 3$ ligand sequences. Remarkably, we demonstrated that a single atom change (oxygen for the sulphur in C62) was sufficient to increase the affinity of EGL1 for $\mathrm{Bcl}-2$ and $\mathrm{Bcl}-\mathrm{x}_{\mathrm{L}}$ by two orders of magnitude (Figure $2 \mathrm{~b}$ ). A further order of magnitude (or greater) increase in affinity for most mammalian pro-survival proteins was achieved by reducing the size of the side chain of $\mathrm{C} 62$ further by replacing it with glycine. This EGL-1BH3-C62G mutant engages Bcl-2 and $\mathrm{BCl}-\mathrm{x}_{\mathrm{L}}$ with an affinity approaching the highest affinity mammalian $\mathrm{BH} 3$ ligands for these pro-survival proteins. ${ }^{23}$

The requirement for a small residue at position 62 in EGL-1 reflects the sterically constrained nature of the binding groove in mammalian pro-survival proteins where this residue is inserted. ${ }^{16-18,23}$ Indeed, a recent study demonstrated that the serine in the corresponding position in $\mathrm{BadBH} 3$ becomes phosphorylated and loses significant affinity for pro-survival proteins. ${ }^{31}$ We also showed that substitution of the glycine in 
Bim at the same position to glutamate is detrimental to binding pro-survival proteins, rendering it inactive. ${ }^{29}$ Interestingly, this region of EGL-1 is adjacent to where the large conformational change occurs to CED-9 required for dissociation of CED-4. ${ }^{13,15}$ However, we also showed that a larger residue is not essential to induce this conformational change as both serine- and glycine-substituted EGL-1 peptides dissociated the CED-4:CED-9 complex (Figure 2e). Moreover, as Bcl- $\mathrm{x}_{\mathrm{L}}$ and $\mathrm{Mcl}-1$ show less plasticity compared to CED-9 in the corresponding region, ${ }^{16-18,32}$ this may explain the intolerance of these molecules for the cysteine in the EGL-1BH3 ligand. This finding has important implications for $\mathrm{BH} 3$ mimetic drug design as it demonstrates that minute changes to ligands can have significant consequences on binding affinities.

\section{Materials and Methods}

Recombinant proteins and synthetic peptides. Expression and purification of human $\mathrm{Bcl}-\mathrm{x}_{\mathrm{L}} \Delta \mathrm{C} 25$, mouse/human $\mathrm{Mcl}-1$ or $\mathrm{N}$-terminal $\mathrm{His}_{6}$-tagged human Bcl-2 $\Delta$ C22 and human Bcl-w $\Delta$ C29 (C29S, A129E), CED-9(68-251) and CED4:CED-9 complex have been previously described. ${ }^{22,23,32}$ Synthetic peptides were synthesized by Mimotopes (Victoria, Australia) and purified by reverse-phase high-performance liquid chromatography to $70-90 \%$ purity.

Solution competition assays. Solution competition assays using the Biacore optical biosensor were performed essentially as described previously. ${ }^{23}$ Pro-survival proteins $(10 \mathrm{nM})$ were incubated with varying concentrations of synthetic peptides for $2 \mathrm{~h}$ prior to injection onto a CM- 5 sensor chip with either wildtype BimBH3 or the inert BimBH3-4E mutant peptide immobilized. ${ }^{23}$ The specific response was determined by subtracting the background signal on the BimBH3-4E mutant channel from the specific signal on the wild-type BimBH3 channel.

Isothermal titration microcalorimetry. ITC studies were performed using a MicroCal VP-ITC instrument. Proteins diluted to $5 \mu \mathrm{M}$ (CED-9) or $10 \mu \mathrm{M}$ (Bcl-2) in Tris-buffered saline (TBS) and peptides (prepared in the same buffer from $2 \mathrm{mM}$ stocks) were injected from a $40 \mu \mathrm{M}$ (EGL-1BH3 C62G) or $400 \mu \mathrm{M}$ (wild-type $\mathrm{EGL}-1 \mathrm{BH} 3$ ) solution at $25^{\circ} \mathrm{C}$. Data analysis was performed using the MicroCal Origin software.

Direct binding assays. Direct binding assays were performed at room

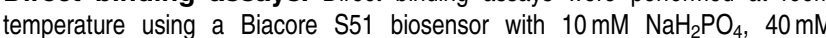
$\mathrm{Na}_{2} \mathrm{HPO}_{4}, 150 \mathrm{mM} \mathrm{NaCl}, 1 \mathrm{mM}$ EDTA, $0.03 \%$ (v/v) Tween 20, 5\% (v/v) DMSO, pH 7.4 as the running buffer. Anti-GST was immobilized on a CM5 sensorchip using amine-coupling chemistry. Recombinant GST-tagged Bcl- $\mathrm{x}_{\mathrm{L}}$ or Mcl-1 $(100 \mu \mathrm{g} / \mathrm{ml})$ were then injected at the flow rate of $10 \mu / \mathrm{min}$ and captured by the tag. All BH3 domain peptides were prepared in running buffer. Several concentrations of peptide around that peptide's $K_{\mathrm{D}}$ were injected at a flow rate of $90 \mu / \mathrm{min}$. Weaker binding ligands $\left(K_{D}>10 \mathrm{nM}\right)$ were allowed to associate with the protein for $60 \mathrm{~s}$ and dissociation was monitored for $60 \mathrm{~s}$, whereas for tighter ligands the association time was $90 \mathrm{~s}$ and the dissociation time was $270 \mathrm{~s}$. All sensorgrams were generated using double referencing by subtracting the binding response from a reference spot, followed by corrections for solvent bulk shifts and subtraction of an average of the running buffer bank injections over the immobilized spot. For $K_{\mathrm{D}}$ calculation, corrected response data were fitted using a 1:1 binding site model including mass transport limitations.

Co-immunoprecipitation of pro-survival proteins and $\mathrm{Bim}_{\mathbf{S}}$ or EGL-1. FLAG-tagged mammalian expression vectors for human Bcl-2, mouse $\mathrm{BCl}-\mathrm{X}_{\mathrm{L}}$ and $\mathrm{HA}$-tagged human $\mathrm{Bim}_{\mathrm{S}}, \mathrm{Bim}_{\mathrm{S}} 4 \mathrm{E}, \mathrm{EGL}-1$ or its mutants subcloned into pEF PGKpuro have been previously described. ${ }^{23,24,33,34}$ The maintenance, transfection and metabolic labelling of HEK293T cells with ${ }^{35} \mathrm{~S}$-methionine/ cysteine, as well as co-immunoprecipitation experiments have been also described previously. ${ }^{33-35}$ Cell lysates were immunoprecipitated with $\sim 5 \mu \mathrm{g}$ antibody (antiHA HA.11, Covance Research Products; anti-FLAG M2, Sigma) and control antiGlu-Glu (anti-EE; Covance Research Products) as previously described. ${ }^{24}$ The proteins were resolved by SDS-PAGE, transferred onto nitrocellulose membranes and immunoprecipitated proteins were detected by fluorography using Amplify (Amersham Biosciences)

CED-4/CED-9 complex dissociation assays. Dissociation of the recombinant CED-4/CED-9 complex was performed by incubation of $100 \mu \mathrm{g}$ of protein $(0.5 \mathrm{mg} / \mathrm{ml})$ with a twofold molar excess of synthetic $\mathrm{BH} 3$ domain peptide in a total volume of $200 \mu \mathrm{l}$ for $1 \mathrm{~h}$ at room temperature. ${ }^{22}$ The reaction mixture was then centrifuged for $5 \mathrm{~min}$ at 13000 r.p.m. in a bench-top microfuge prior to chromatography on a Superose $610 / 30$ column equilibrated and run in TBS at $0.5 \mathrm{ml} / \mathrm{min}$

Killing assays. Retroviral expression constructs were made using the pMIG vector (MSCV-IRES-GFP; GFP sequence is that of EGFP) as described previously. ${ }^{23,36}$ Following transient transfection into Phoenix Ecotropic packaging cells, ${ }^{37}$ filtered virus-containing supernatants were used to infect SV40 large T-antigen transformed MEFs by spin inoculation as described previously ${ }^{23}$ and cell viability was determined by flow cytometric analyses of infected cells (GFP ${ }^{+}$) that excluded $5 \mu \mathrm{g} / \mathrm{mL}$ propidium iodide (Sigma) which was analysed using FACScan ${ }^{\circledR}$ (Becton Dickinson).

For long-term survival (colony) assays, wild-type, $m \mathrm{cl}^{-1^{-1-}}, \mathrm{bcl}-\mathrm{x}^{-1-}$ MEF cell lines or those expressing either, human Noxa or mouse Bad were infected with retroviruses as above, grown in the presence of $50 \mu \mathrm{M}$ QVD-OPH for $24 \mathrm{~h}$ and then $150 \mathrm{GFP}^{+}$cells were sorted into six-well plates in the absence of QVD-OPH. Colonies were allowed to grow for 6 days prior to staining with Coomassie brilliant blue and were counted.

EGL-1 stability experiments. MEFs were infected with retroviruses in which expression of HA-tagged EGL-1, EGL-1-C62G, Bim ${ }_{S} E G L-1 B H 3$ chimeras or $\mathrm{Bim}_{\mathrm{S}}$ was linked to GFP in the pMIG vector. GFP ${ }^{+}$cells were selected by FACS sorting and were expanded. Equivalent numbers of cells $(200000)$ were then treated with $50 \mu \mathrm{g} / \mathrm{ml}$ cycloheximide for 0-9 h after which time they were lysed, and analysed for HA-tagged protein levels by western blotting using the anti-HA antibody (HA.11; Covance Research Products). Blots were re-probed with antiHSP-70 as a loading control.

In vitro cytochrome $\boldsymbol{c}$ release assays. Cytochrome $c$ release assays were performed as previously described ${ }^{38}$ using mitochondria-containing crude lysates from digitonin-permeabilized MEFs that were stably transfected with either human Noxa or mouse Bad. The lysates were either left untreated or incubated with the synthetic peptide $(10 \mu \mathrm{M})$ at $30^{\circ} \mathrm{C}$ for $1 \mathrm{~h}$ before pelleting. The supernatant was retained as the soluble $(S)$ fraction whereas the pellet $(P)$ fraction, which contains unpermeabilized mitochondria, was solubilized in RIPA buffer. Both the soluble and pellet fractions were then subjected to SDS-PAGE and proteins were transferred to nitrocellulose membranes, which were immunoblotted using a mouse monoclonal anti-cytochrome $c$ (7H8.2C12; BD Pharmingen) antibody followed by rabbit polyclonal anti-Bak (B5929; Sigma) antibody.

Acknowledgements. We thank $\mathrm{H}$ lerino, $\mathrm{K}$ Knezevic and $\mathrm{M}$ Evangelista for technical assistance; R Anderson, S Korsmeyer, N Motoyama, C Thompson, and W Welch for reagents and A Strasser, $P$ Bouillet, $P$ Kelly and $M$ van Delft for the $m \mathrm{ml}-1^{-1-}$ cells. This work was supported by grants from the Australian NHMRC (Program Grant 257502), US NCl (CA80188), Leukemia and Lymphoma Society (Specialized Center of Research 7015-02), the Cancer Council of Victoria (Project 461239), fellowships and scholarships from the NHMRC (DCSH, WDF, PMC) and the Cancer Council of Victoria (PMC - Fraser Fellowship, EFL).

1. Horvitz HR. Genetic control of programmed cell death in the nematode Caenorhabditis elegans. Cancer Res 1999; 59 (7 Suppl): 1701s-1706s.

2. Hengartner MO, Horvitz HR. C. elegans cell survival gene ced-9 encodes a functional homolog of the mammalian proto-oncogene bcl-2. Cell 1994; 76: 665-676.

3. Zou H, Henzel WJ, Liu X, Lutschg A, Wang X. Apaf-1, a human protein homologous to C. elegans CED-4, participates in cytochrome $c$-dependent activation of caspase-3. Cell 1997; 90: 405-413.

4. Chinnaiyan AM, Chaudhary D, O'Rourke K, Koonin EV, Dixit VM. Role of CED-4 in the activation of CED-3. Nature 1997; 388: 728-729.

5. Conradt $\mathrm{B}$, Horvitz HR. The $C$. elegans protein EGL-1 is required for programmed cell death and interacts with the Bcl-2-like protein CED-9. Cell 1998; 93: 519-529. 
6. del Peso L, González VM, Núñez G. Caenorhabditis elegans EGL-1 disrupts the interaction of CED-9 with CED-4 and promotes CED-3 activation. J Biol Chem 1998; 273 33495-33500

7. del Peso L, González VM, Inohara N, Ellis RE, Núñez G. Disruption of the CED-9/CED-4 complex by EGL-1 is a critical step for programmed cell death in $C$. elegans. J Biol Chem 2000; 275: 27205-27211.

8. Spector MS, Desnoyers S, Hoeppner DJ, Hengartner MO. Interaction between the $C$. elegans cell-death regulators CED-9 and CED-4. Nature 1997; 385: 653-656.

9. Wu D, Wallen HD, Inohara N, Nuñez G. Interaction and regulation of the Caenorhabditis elegans death protease CED-3 by CED-4 and CED-9. J Biol Chem 1997; 272: 21449-21454.

10. Wu DY, Wallen HD, Nuñez $G$. Interaction and regulation of subcellular localization of CED-4 by CED-9. Science 1997; 275: 1126-1129.

11. Yan N, Chai J, Lee ES, Gu L, Liu Q, He J et al. Structure of the CED-4-CED-9 complex provides insights into programmed cell death in Caenorhabditis elegans. Nature 2005; 437: 831-837.

12. Chen F, Hersh BM, Conradt B, Zhou Z, Riemer D, Gruenbaum $Y$ et al. Translocation of $C$. elegans CED-4 to nuclear membranes during programmed cell death. Science 2000; 287 1485-1489.

13. Yan N, Gu L, Kokel D, Chai J, Li W, Han A et al. Structural, biochemical, and functional analyses of CED-9 recognition by the proapoptotic proteins EGL-1 and CED-4. Mol Cell 2004; 15: 999-1006.

14. Woo JS, Jung JS, Ha NC, Shin J, Kim KH, Lee W et al. Unique structural features of a BCL-2 family protein CED-9 and biophysical characterization of CED-9/EGL-1 interactions. Cell Death Differ 2003; 10: 1310-1319.

15. Yan N, Chai J, Lee ES, Gu L, Liu Q, He J et al. Structure of the CED-4-CED-9 complex provides insights into programmed cell death in Caenorhabditis elegans. Nature 2005; 437: 831-837.

16. Petros AM, Nettseheim DG, Wang Y, Olejniczak ET, Meadows RP, Mack J et al. Rationale for $\mathrm{Bcl}-\mathrm{x}_{\mathrm{L}} / \mathrm{Bad}$ peptide complex formation from structure, mutagenesis, and biophysical studies. Protein Sci 2000; 9: 2528-2534.

17. Liu X, Dai S, Zhu Y, Marrack $P$, Kappler JW. The structure of a $B c l-x_{L} / B i m$ fragment complex: implications for Bim function. Immunity 2003; 19: 341-352.

18. Sattler M, Liang H, Nettesheim D, Meadows RP, Harlan JE, Eberstadt M et al. Structure of Bcl- $\mathrm{X}_{\mathrm{L}}$-Bak peptide complex: recognition between regulators of apoptosis. Science 1997; 275: 983-986.

19. Vaux DL, Weissman IL, Kim SK. Prevention of programmed cell death in Caenorhabditis elegans by human bcl-2. Science 1992; 258: 1955-1957.

20. Jabbour AM, Puryer MA, Yu JY, Lithgow T, Riffkin CD, Ashley DM et al. Human Bcl-2 cannot directly inhibit the Caenorhabditis elegans Apaf-1 homologue CED-4, but can interact with EGL-1. J Cell Sci 2006; 119 (Part 12): 2572-2582.

21. Delivani P, Adrain C, Taylor RC, Duriez PJ, Martin SJ. Role for CED-9 and Egl-1 as regulators of mitochondrial fission and fusion dynamics. Mol Cell 2006; 21: 761-773.

22. Fairlie WD, Perugini MA, Kvansakul M, Chen L, Huang DC, Colman PM. CED-4 forms a 2:2 heterotetrameric complex with CED-9 until specifically displaced by EGL-1 or CED-13. Cell Death Differ 2006; 13: 426-434.
23. Chen L, Willis SN, Wei A, Smith BJ, Fletcher Jl, Hinds MG et al. Differential targeting of prosurvival $\mathrm{Bcl}-2$ proteins by their $\mathrm{BH} 3-$ only ligands allows complementary apoptotic function. Mol Cell 2005; 17: 393-403.

24. Willis SN, Chen L, Dewson G, Wei A, Naik E, Fletcher Jl et al. Proapoptotic Bak is sequestered by $\mathrm{Mcl}-1$ and $\mathrm{Bcl}-\mathrm{xL}$, but not $\mathrm{Bcl}-2$, until displaced by $\mathrm{BH} 3-$ only proteins. Genes Dev 2005; 19: 1294-1305.

25. Willis SN, Fletcher Jl, Kaufmann T, van Delft MF, Chen L, Czabotar PE et al. Apoptosis initiated when $\mathrm{BH} 3$ ligands engage multiple Bcl-2 homologs, not Bax or Bak. Science 2007; 315: 856-859.

26. Certo M, Del Gaizo Moore V, Nishino M, Wei G, Korsmeyer S, Armstrong SA et al. Mitochondria primed by death signals determine cellular addiction to antiapoptotic BCL-2 family members. Cancer Cell 2006; 9: 351-365.

27. Kim H, Rafiuddin-Shah M, Tu HC, Jeffers JR, Zambetti GP, Hsieh JJ et al. Hierarchical regulation of mitochondrion-dependent apoptosis by BCL-2 subfamilies. Nat Cell Biol 2006; 8: $1348-1358$.

28. Kuwana T, Bouchier-Hayes L, Chipuk JE, Bonzon C, Sullivan BA, Green DR et al. BH3 domains of $\mathrm{BH} 3-o n l y$ proteins differentially regulate Bax-mediated mitochondrial membrane permeabilization both directly and indirectly. Mol Cell 2005; 17: 525-535.

29. Lee EF, Czabotar PE, van Delft MF, Michalak EM, Boyle MJ, Willis SN et al. A novel BH3 ligand that selectively targets $\mathrm{Mcl}-1$ reveals that apoptosis can proceed without $\mathrm{Mcl}-1$ degradation. J Cell Biol 2008; 180: 341-355.

30. Del Gaizo Moore V, Schlis KD, Sallan SE, Armstrong SA, Letai A. BCL-2 dependence and ABT-737 sensitivity in acute lymphoblastic leukemia. Blood 2008; 111: 2300-2309.

31. Danial NN, Walensky LD, Zhang CY, Choi CS, Fisher JK, Molina AJ et al. Dual role of proapoptotic BAD in insulin secretion and beta cell survival. Nat Med 2008; 14: 144-153.

32. Czabotar PE, Lee EF, van Delft MF, Day CL, Smith BJ, Huang DC et al. Structural insights into the degradation of Mcl-1 induced by BH3 domains. Proc Natl Acad Sci USA 2007; 104 6217-6222.

33. Moriishi K, Huang DCS, Cory S, Adams JM. Bcl-2 family members do not inhibit apoptosis by binding the caspase-activator Apaf-1. Proc Natl Acad Sci USA 1999; 96: 9683-9688.

34. Huang DCS, O'Reilly LA, Strasser A, Cory S. The anti-apoptosis function of Bcl-2 can be genetically separated from its inhibitory effect on cell cycle entry. EMBO J 1997; 16 4628-4638.

35. O'Connor L, Strasser A, O'Reilly LA, Hausmann G, Adams JM, Cory S et al. Bim: a novel member of the Bcl-2 family that promotes apoptosis. EMBO J 1998; 17: 384-395.

36. Van Parijs L, Refaeli Y, Abbas AK, Baltimore D. Autoimmunity as a consequence of retrovirus-mediated expression of c-FLIP in lymphocytes. Immunity 1999; 11: 763-770.

37. Kinsella TM, Nolan GP. Episomal vectors rapidly and stably produce high-titer recombinant retrovirus. Hum Gene Ther 1996; 7: 1405-1413.

38. Sadowsky JD, Fairlie WD, Hadley EB, Lee HS, Umezawa N, Nikolovska-Coleska Z et al (alpha/beta+alpha)-peptide antagonists of $\mathrm{BH} 3$ domain/ $\mathrm{Bcl}-\mathrm{x}(\mathrm{L})$ recognition: toward general strategies for foldamer-based inhibition of protein-protein interactions. $J A m$ Chem Soc 2007; 129: 139-154. 